\title{
Teacher Training on Classroom Management and Conflict Resolution
}

\author{
Venera Këndusi \\ Albanian Faculty of Education, University of Gjakova, Gjakova, Kosova \\ veneravala@hotmail.com
}

\section{Doi:10.5901/ajis.2015.v4n1s1p151}

\begin{abstract}
This paper includes main criteria on dealing with classroom management and conflict resolution, attributes that any teacher must have and apply. To be a good teacher not only in terms of subject content competence, teachers have to plan and organize, set the rules and procedures to face different and unpredictable situations that can occur in the classroom. To comply and accomplish goals and objectives in teaching and learning, teachers should create a good working atmosphere in their classrooms. Order and discipline in classroom plays a very important role for an effective teaching. In addition, the paper will deal with unpleasant behaviour and problems arising by weak classroom management and teacher skills in preventing them. The aim of it is presenting the importance of creating a positive climate in the classroom, cultivating habits for common work, identifying problems and working together on finding a solution.
\end{abstract}

Keywords: Teacher, classroom management, teacher training, order, positive climate.

\section{Introduction}

Classroom management represents the process of organizing and leading, aiming on achieving teaching objectives. The goal for classroom management mainly has to do with effective teaching time management - it has to be focused in teaching and learning rather than lateral issues.

Classroom management is a very difficult and complicated process, but when done correctly, the effort and endeavour is worth it. It allows teaching strategies to be drafted freely, also improves classroom ethics, group compactness and students motivation, giving a right direction to student efforts to obtain new knowledge (Bojaxhi, 2004).

Classroom management stands on respect for student that can be obtained by treating students fairly and honestly. Indifferent teachers, in most of the cases protect students even though they are not heading in the right direction. Trying to set a positive climate in classroom, the first thing to be done is know your students as individuals as soon as possible and as best as you can. Having in mind that in the classroom there are different students, coming from different families, teachers should have skills to create the feeling of cooperation in between children, prevent and resolve situations whenever necessary, intermediate and arbitrate in relation to them or the various problems inside and outside teaching process. The problem might be a challenge but not an obstacle. Problems in teaching process are an inherent factor since we are part of day to day process and within various situations various and unexpected problems can appear. Often, different problematic situations are those that disclose what student need, their requests, worries, wishes as well as skills, directions, competences, intelligence and their personality.

A teacher has a great influence in classroom management. An effective teaching is closely related to classroom management. Hence the efficient teacher who is aware of methods and ways of working, teaching strategies and techniques, motivation for students, their assessment is the teacher who is competent in classroom management also. In classroom management we can include creation of a positive climate in classroom. Classroom teacher has a decisive role in creating a positive climate, his professional abilities and skills to create a positive environment in a classroom. Classroom environment created by teacher can influence student motivation, thereby reflecting in their active attitude toward learning. Exactly that environment represents what is called "classroom climate". (Musai, 2003).

Teacher should have skills for organizing a physical environment for students, that impacts inclusion and participation of all students in classroom organised activities. Another factor influencing is student's motivation, being an incentive to student's activities, their interest and willingness. So motivation is a process initiated by teacher and stimulates interest on certain issues using creativity, incentive, attention, gratitude and compliments.

It is important to set up rules in a classroom. For the rules to be acknowledged and applied, it is preferable that teachers and students together decide on them in the beginning of school year. Student participation in setting up the 
rules makes it easier for students to memorise and implement them. Classroom rules should be repeated several times and if necessary improvements might be done, or addition rules added if appropriate. In addition, it is better to write down these rules and have them in a board where any student can see and read them and the parents have to be aware of them, too. Setting up rules and discipline in a classroom results in a better classroom organization and management, in a better cooperation and communication in between students, teachers and parents. Rules can help preventing unpleasant behaviour, conflicts and problems that might come up in the classroom.

Conflicts and problems present in a classroom result from student socio economic situation, emotional problems, weak cooperation and communication in between students them self, teacher professional competences, teacher communication skills, teaching program quality, regular cooperation in between teacher and parents.

It is the duty of teachers to prevent and solve the conflicts, as part of classroom management, creation of a positive climate in classroom. This is the reason why parent's inclusion in education is indispensable. By including parents in education we understand information on issues affecting children life, different ways of supporting children at school, hence it is the key to help children become successful. (Karaj, 2008)

Accepting the view that a child comes in this world as a fragile human been, lays down many duties and responsibility ahead, whose initial ground must be a sound ethical-educational upbringing. It is the duty of teachers to cultivate on them courtesy, discipline, commitment to work, humanity, solidarity, cooperation, etc. Only then, there is assurance that we can expect much more favourable result in any field in the future, preventing bad and malicious habits through rules of courtesy, tolerance and mutual understanding.

Children social and ethical development also is a duty of a teacher. Children ethical education does not depend only on individual predispositions but teacher skills and educational - teaching syllabus as well. Teachers should cultivate in students the feeling of love toward parents, family, country, develop sense of friendship and society and sense of cooperation and mutual assistance, develop elementary working and cultural habits and develop positive features of willingness and character (Veseli, 2005).

The process of teaching habits to children is done through concrete channels, day to day life events, unconscious imitation and positive stimulation and motivation for building up healthy habits and morally desirable behaviour.

It takes years for a child to learn and embrace ethical norms in the life cycle. All the habits, that can take form latter on in a child, are learnt through his experience in different life situations. Through experience he learns that some behaviourare "good" while some others are" bad". The role of a teacher in these circumstances is very important, because we have to influence in real situations using adequate strategy in developing and complementing good behaviour, and suppressing or interrupting bad behaviour.

Cooperation in solving problems has a central role in social and cognitive development of children. Common activities of children with other children of their age play an efficient role in enhancing their knowledge and obtaining different experiences. While interacting with other children of their own age they learn new skills, motivate each other to face challenging situations and help each other in practising skills they possess. A special type of solving problems is through interaction and cooperation, where teachers should stimulate children to interact, change behaviour and processes and inspire cooperation. That can especially be achieved through games. When two children work on solving a problem they show up their individuality, exchange experiences and increase level of confidentiality and socialisation (Karaj. 2005).

\section{Research methodology}

Main goal of this research is evidencing the actual state of classroom management by teachers in primary schools in Gjakova, keeping in mind academic aspect, relationship with students and parent. This research provides a very good opportunity to understand teacher's professional skills in managing classroom and preventing conflicts and problems in classroom.

\section{Research Methods and Techniques}

To conduct research and study the issue the following research methods are used:

- Theoretical analyses method

- Verbal method

- Descriptive method 


\section{Sample}

The nature of the research itself imposes a small number of respondents. Research is conducted with teachers of primary schools in Gjakova.

The interview is used to come up with as many data as possible and creating facilities for respondents to answer the questions.

Research is done with 5 teachers from primary school "KelmendRizvanolli"inGjakova.

Teacher age: $35-45$ years old

Gender: Female

Working experience: $10-20$ years of work

Following are the results from the research:

\section{Some of the Questions Asked}

1. Is classroom management one of the major worries for teachers?

"I believe good classroom management is one of the most difficult tasks of teaching"

"Teacher has several important tasks in teaching process, one of them in good classroom management"

"Classroom management means a lot to a teacher because management problems include creation and maintainace of a positive climate in classroom, resulting in effective learning"

\section{Do you set up rules in classroom?}

"We set up classroom rules in the beginning of school year together with students"

"Yes, we set up the rules together with students and the parents are informed on these rules as well"

3. Do students always implement those rules or i t happens that you face problems and conflicts in classroom?

"Sometimes happens that some of the students do not apply the rules and we have problems"

"It often happens that rules are not adhered and mostly there are teasing and hold backs in work of other students."

"It happens to have problems in classroom and conflicts of low degree, but I try to prevent these problems"

4. Have you participated in any program of professional training dealing with classroom management or help in resolving problems and conflicts in classroom?

"No I haven't been part of any special program on classroom management"

"Some of the trainings I attended included some lectures on resolving problems in classroom, but I haven't been part of such a special designed training on classroom management"

"I attended the training on Children Rights; I haven't had the chance to attend any other specific training on classroom management"

\section{Conclusions and Recommendation}

Teachers face different difficulties during teaching process. One of them is classroom management, creating a positive climate in classroom, order and discipline in classroom. A teacher should possess organisational skills, be prepared on professional, methodical and didactic aspects.

Hence we recommend deeper research and analyses on identifying weaknesses in classroom management, have regular cooperation in between teachers and parents, teachers should be aware of their students skills, knowledge, social, economic and emotional state. Ministry of Education and school should organize programs on professional training and development of teachers so they could be more familiar with classroom management, trainings for teachers on issues that are related directly to children psychology. 


\section{References}

Bojaxhi,A.(2004).Discipline in class learning. Tirana:Toena.

Karaj, T. (2008). Classroom management. Tirana: EMAL.

Karaj, T.(2005). The psychology of child development. Tirana:Progres.

Musaj.B.(2003).Methodology of teaching.Tirana:Pegi

Veseli.A(2005).School pedagogy. Gjilan:University of Prishtina. 